\title{
IMPLEMENTASI PENGEMBANGAN ENTERPRENEURSHIP DALAM KURIKULUM PRODI PGMI INSTITUT PESANTREN MATHALI'UL FALAH PATI-JAWA TENGAH
}

\author{
Inayatul Ulya \\ Institut Pesantren Mathali'ul Falah Pati \\ ulyain@yahoo.com
}

\begin{abstract}
Abstrak
Salah satu masalah yang dihadapi oleh negara-negara berkembang adalah jumlah orang yang hidup dalam kemiskinan. Karena itu, pengentasan kemiskinan merupakan prioritas dalam pelaksanaan pembangunan ekonomi. Bagi Indonesia, pengurangan kemiskinan merupakan salah satu ukuran keberhasilan pembangunan. Mengingat jumlah penduduk dunia dalam kemiskinan, wajar jika kemiskinan menjadi masalah internasional. Ini membuktikan, PBB telah menetapkan Millenium Development Goals (MDGs), di mana salah satu tujuannya adalah untuk mengurangi kemiskinan. Sebagai peserta konferensi tingkat tinggi milenium PBB, Indonesia secara serius mengurangi jumlah orang miskin mencapai 50\% pada tahun 2015. Kemiskinan adalah isu yang kompleks, sehingga penanggulangan memerlukan pendekatan dari berbagai aspek, baik ekonomi, politik dan sosial budaya. . Salah satu solusinya adalah melalui kegiatan edukasi berwirausaha untuk mengubah sikap mental ketergantungan dan mengembangkan etos kerja, yang diharapkan bisa menumbuhkan kemandirian. Melalui penerapan pendidikan kewirausahaan diharapkan dapat meningkatkan kesadaran bahwa untuk menghilangkan kemiskinan harus dilakukan melalui kerja produktif yang dilakukan sendiri. Kemudian, Prodi PGMI dari Institut Pesantren Mathali'ul Falah bermaksud mengembangkan kewirausahaan dalam desain kurikulum dan pengalaman belajar sehingga lulusan dapat bertahan dalam hidupnya nantinya.
\end{abstract}

Kata-kata kunci: Pengembangan kewirausahaan dan Kurikulum Prodi

\begin{abstract}
One of the problems faced by countries emerging is the number of people living in poverty. Therefore, poverty reduction a priority in the implementation of economic development. For Indonesia, the reduction of poverty is one measure of the success of development. Considering the number of the world's population in poverty, it is natural for poverty become an international problem. It proved, the PBB has set Millennium Development Goals ( MDGs ), where one of the goal is to reduce poverty . as a high-level conference participants millenium of $P B B$, Indonesia seriously to reduce the number of poor people to reach $50 \%$ by 2015. Poverty is a complex issue, so that countermeasures need approaches from various aspects, whether economic, political and socio-cultural. One of the solutions is through educational activities entrepreneurship in order to change the mental attitude of dependence and to develop a work ethic, which is expected to
\end{abstract}


foster self-reliance. Through the implementation of entrepreneurship education is expected to raise the awareness that to eliminate poverty must be taken through the productive work carried out by their own. Then, Prodi PGMI of Institut Pesantren Mathali'ul Falah intends to develop entrepreneurship in the curriculum design and learning experiences so that graduates can survive in his life later

Keywords: Entrepreneurship education and Prodi

\section{A. Pendahuluan}

Pendidikan tinggi memiliki banyak problematika yang riil dihadapi akhirakhir ini. Diantaranya banyaknya lulusan pendidikan tinggi yang tidak mampu terserap dalam dunia kerja. Berdasarkan data dari Badan Pusat Statistik (2009) menyebutkan bahwa tingkat pengangguran terbuka di Indonesia mencapai 7,87\%. Data lain dari sumber yang sama mengindikasikan adanya kenaikan jumlah penduduk yang bekerja menurut pendidikan tertinggi yang ditamatkan untuk golongan SMK, diploma, dan universitas. Untuk pekerja dengan pendidikan diploma hanya sebesar 2,79 juta orang atau sekitar 2,55 persen, dan pekerja dengan pendidikan sarjana hanya tercatat sebesar 4,66 juta orang atau mencapai 4,44 persen. Data tersebut diperkuat dari informasi yang diperoleh Harian Suara Pembaharuan bahwa pada tahun 2005 jumlah sarjana yang menganggur sebanyak 183.629 orang dan tahun 2006 tercatat 409.890 lulusan tidak memiliki pekerjaan, tahun 2007 menjadi 740.000 dan awal tahun 2009 melonjak mendekati angka satu juta sarjana pengangguran (Ning Tias, 2009: 2). Sedangkan data yang dihimpun Harian Kompas menyebutkan bahwa angka pengangguran keseluruhan berada pada kisaran $10,8 \%$ sampai dengan $11 \%$ dari tenaga kerja yang masuk pada pengangguran terbuka, termasuk sekitar 1.100 .000 alumni perguruan tinggi (Winarno, 2013). Data tersebut menunjukkan bahwa pengangguran khususnya lulusan pendidikan tinggi menjadi masalah yang cukup beralasan untuk segera dicarikan alternatif solusi.

Problematika lain yang dihadapi pendidikan tinggi adalah rendahnya kompetensi lulusannya sehingga out put dari pendidikan tinggi belum mempunyai kompetensi yang diharapkan dan dibutuhkan masyarakat serta mempunyai daya saing rendah dalam dunia kerja. Kondisi tersebut di atas didukung pula oleh 
kenyataan bahwa sebagian besar lulusan perguruan tinggi cenderung lebih sebagai pencari kerja (job seeker) daripada pencipta lapangan pekerjaan (job creator). Hal ini kemungkinan disebabkan sistem pembelajaran yang diterapkan di berbagai perguruan tinggi saat ini lebih terfokus pada bagaimana menyiapkan para mahasiswa yang cepat lulus dan mendapatkan pekerjaan, bukannya lulusan yang siap menciptakan pekerjaan. Di samping itu, aktivitas kewirausahaan (entrepreneurial activity) yang relatif masih rendah. Umumnya alumni perguruan tinggi memilih untuk bekerja di perusahaan-perusahaan besar ataupun bekerja pada instansi pemerintah atau menjadi PNS. Pekerjaan-pekerjaan pada sektor tersebut dianggap memberi income yang menggiurkan sekaligus status sosial yang cukup tinggi di masyarakat.

Rendahnya kompetensi lulusan dari Perguruan Tinggi tersebut menjadikan Perguruan Tinggi terkesan hanya mampu memproduk pemegang gelar S1 atau S2 tetapi secara kualitas out put dari pendidikan tinggi ini masih rendah karena belum mempunyai kompetensi sesuai dengan harapan masyarakat dan dunia kerja. Perguruan Tinggi selama ini sering terjebak dengan upaya pemberian teori-teori untuk memperbanyak mahasiswa secara kuantitas tanpa berupaya mengevaluasi dan menganalisa seberapa banyak produk pendidikannya yang terserap dalam dunia kerja (Ruwiyanto, 1994: 3).

Berdasarkan beberapa problematika dalam pendidikan tinggi tersebut menunjukkan adanya gap antara das sein dan das sollen (antara kenyataan dan harapan). Sehingga pendidikan tinggi sudah saatnya melakukan evaluasi dan mencari alternatif solusi. Salah satu upaya yang dapat dilakukan pendidikan tinggi khususnya PTKI (Perguruan Tinggi Keagamaan Islam), diantaranya dengan melakukan pengembangan kurikulum berbasis kewirausahaan. Pengembangan kurikulum berbasis kewirausahaan ini diperlukan dalam rangka merespon link and match antara out put dengan lapangan kerja. Pengembangan kurikulum berbasis kewirausahaan tersebut dapat dilakukan dengan memberikan pendidikan kewirausahaan (entrepreneurship) secara integral dalam rancangan kurikulum pendidikannya. 
Pengembangan kurikulum berbasis kewirausahaan tersebut hendaklah juga direspon oleh Program Studi PGMI sebagai bentuk respon atas konsep link and match agar lulusan Prodi PGMI memiliki keterampilan kewirausahaan disamping keterampilan menjadi guru MI. Berdasarkan hal-hal diatas, maka Program Studi Pendidikan Guru Madrasah Ibtidaiyah (Prodi PGMI) yang merupakan salah satu program studi baru yang ada di Institut Pesantren Mathali'ul Falah (IPMAFA) yang baru memiliki izin operasional pada Bulan Juni 2015 berdasarkan SK Direktur Jendral Pendidikan Islam Nomor 3668 Tahun 2015 berkomitmen untuk mengembangkan entrepreneurship dalam kurikulum pendidikannya. Prodi PGMI Institut Pesantren Mathali'ul Falah memilih entrepreneurship sebagai distingsi yang membedakan Prodi PGMI di Institut Pesantren Mathali'ul Falah dengan Prodi PGMI di tempat lain. Kebijakan memilih entrepreneurship sebagai distingsi di Prodi PGMI tersebut kemudian masuk dalam desain dan pengembangan kurikulum di Prodi PGMI. Berdasar pada pemaparan permasalahan tersebut di atas, adapun yang menjadi tujuan penulisan artikel ini adalah bagaimana implementasi pengembangan enterpreneurship dalam kurikulum prodi PGMI Institut Pesantren Mathali'ul Falah Pati-Jawa Tengah?

\section{B. Metode Penelitian}

Penelitian ini merupakan penelitian kepustakaan (library research) yakni suatu penelitian yang pengumpulan datanya dilakukan dengan menghimpun data dari berbagai literatur. Penelitian ini juga merupakan merupakan penelitian deskriptif analitik yakni berusaha memaparkan data-data terkait dengan implementasi pengembangan enterpreneurship dalam kurikulum prodi PGMI Institut Pesantren Mathali'ul Falah Pati-Jawa Tengah.

\section{Hasil Penelitian dan Pembahasan}

\section{Urgensi Pendidikan Kewirausahaan di Prodi PGMI}

Pendidikan merupakan usaha yang dilakukan secara sadar untuk mendewasakan dan mengubah tingkah laku seseorang. Kegiatan pendidikan direncanakan, diatur, dimonitor dan dievaluasi agar mampu mencapai tujuan yang 
telah ditentukan. Manusia memiliki berbagai potensi yang dapat dikembangkan melalui pendidikan. Dengan pendidikan, kompetensi intelektual, kompetensi sosial, kompetensi emosional dan kompetensi moral dapat dibentuk dan dikembangkan. Selain itu, dengan pendidikan, pengetahuan, sikap dan keterampilan dapat ditingkatkan. Dalam konteks ini, pendidikan entrepreneurship (kewirausahaaan) diperlukan sebagai bekal mahasiswa untuk menghadapi masa depannya. Secara terperinci urgensi pendidikan kewirausahaan di perguruan tinggi dapat dianalisa berdasarkan hal-hal berikut:

1. Membentuk karakter kewirausahaan mahasiswa

Pendidikan kewirausahaan di Prodi PGMI bertujuan untuk membentuk mahasiswa secara utuh (holistik), sebagai insan yang memiliki karakter, pemahaman dan ketrampilan sebagai wirausaha. Pada dasarnya, pendidikan kewirausahaan dapat diimplementasikan secara terpadu dengan kegiatan-kegiatan pendidikan di perguruan tinggi. Pelaksanaan pendidikan kewirausahaan dilakukan oleh seluruh sivitas akademika karena diupayakan agar pelaksanaan pendidikan kewirausahaan ini tidak sekedar berada dalam ranah teori tetapi lebih ditekankan pada aplikasi dan aktivitas riil kewirausahaan dan bahkan menjadi kultur dalam kehidupan kampus. Dalam rangka untuk merealisasikan hal tersebut, desain kurikulum yang tepat sangat diperlukan dalam rangka mengukur aspek-aspek yang akan diberikan pada mahasiswa, konsistensi materi dan keselarasan dalam setiap program kewirausahaan.

Pendidikan entrepreneurship (kewirausahaan) ini penting sebagai bekal bagi para mahasiswa untuk memahami teori-teori dan nilai-nilai kewirausahaan dan berbagai macam keterampilan kerja (work skill). Tujuannya dapat menggeser mindset lulusan perguruan tinggi yang mayoritas ingin menjadi karyawan perusahaan dan menjadi pegawai negeri sipil (PNS). Berbekal keterampilan enterpreneurial yang pernah diperoleh di bangku kuliah akan bermanfaat menjadi sebuah kemampuan untuk mengelola, memberdayakan dan menginternalisasi pengetahuan akademis dalam mengatasi masalah, kesulitan dan tantangan yang dihadapi yang akhirnya memunculkan kreativitas dan inovasi untuk menciptakan lapangan kerja sendiri dan tidak tergantung untuk selalu melamar kerja, padahal 
lowongan pekerjaan tidak selalu dibuka setiap saat. Kalaupun banyak lowongan pekerjaanpun terkadang kuotanya tidak seimbang dengan lulusan perguruan tinggi.

Melalui pendidikan kewirausahaan di perguruan tinggi secara perlahan jiwa dan karakter kewirausahaan akan terbentuk dan terinternalisasi dalam setiap pemikiran dan tindakan mahasiswa sehingga akan menjadikan lulusannya menjadi pribadi yang dapat selalu berpikir, bersikap dan bertindak kreatif dan inovatif dalam berbagai konteks kehidupan. Karena sejatinya seorang entrepreneur itu tidak sekedar berdagang tetapi jiwa kewirausahaan dapat diimplementasikan dalam setiap aspek kehidupan.

Upaya mengembangkan kewirausahaan, selain mahasiswa yang masih duduk di bangku kuliah, out put dan out come perguruan tinggi juga memiliki peran penting memainkan peranannya. Hal ini dapat dipahami sebagai proses long life education (pendidikan seumur hidup) lulusan perguruan tinggi diharapkan dapat mengembangkan keterampilan individu, sikap dan perilaku baik dalam dunia kerja maupun dalam konteks kehidupan secara umum. Sehingga jiwa kewirausahaan yang telah terinternalisasi dalam bangku kuliah dapat diaplikasikan secara riil dalam kehidupan sehari-hari.

2. Membuka mindset kewirausahaan mahasiswa

Mahasiswa sejak awal perlu diberi pencerahan tentang manfaat penting menjadi entrepreneur dengan dibuka pola fikirnya agar ketekunan dan keseriusan dalam kuliah tidak hanya berorientasi pada satu target, yaitu mencari kerja saja. Apabila pola fikir semacam ini terus tertanam dalam diri setiap mahasiswa, resikonya ketika mereka lulus, kemudian tidak memperoleh pekerjaan sesuai yang mereka harapkan, maka mereka akan merasa gagal dan tidak sukses. Setelah mereka merasa gagal, kemudian secara terpaksa menjadi wirausahawan. Menjadi wirausahawan dengan dasar keterpaksaan ini juga akan menjadikan pelaku usaha tersebut menjadi kurang nyaman dan kurang siap dengan berbagai tantangan dan hambatan-hambatan dalam menjalani usahanya.

Berdasarkan hal-hal di atas, maka sebaiknya dari awal paradigma berfikir mahasiswa sudah mulai diorientasikan tentang hal-hal positif sebagai seorang entrepreneur. Karena menjadi seorang entrepreneur itu tidak sekedar menjadi pengusaha, tetapi kemampuan seseorang untuk membuka mata, telinga dan sensitivitas di sekitar kita, untuk melihat peluang, bahkan merubah masalah dan kesulitan menjadi 
peluang serta kemampuan untuk menemukan kreativitas-kreativitas dan inovasi dalam dunia usaha.

3. Tuntutan kebutuhan pengembangan kurikulum kewirausahaan di perguruan tinggi

Pendidikan di perguruan tinggi seringkali menawarkan keterampilan keilmuan dan keterampilan kerja tertentu sesuai dengan bidang kerja yang banyak dibutuhkan dalam masyarakat. Sehingga, jurusan dan program studi yang dibuka disesuaikan dengan tingkat popularitas dan kebutuhan dunia kerja. Selain itu, menjadi kredit poin tersendiri bagi perguruan tinggi yang lulusannya banyak terserap di dunia kerja. Sehingga, mayoritas perguruan tinggi bangga dan berlomba-lomba agar prosentase lulusan yang terserap di dunia kerja semakin meningkat dari tahun ke tahun. Kebanggaan tersebut akan semakin besar ketika lulusan yang diserap dunia kerja tersebut sesuai keahlian keilmuan sesuai bidang keilmuan yang dipilih dan ditekuni waktu kuliah di perguruan tinggi tersebut.

Bertolak dari hal-hal di atas, perguruan tinggi saat ini dihadapkan pada realita sempitnya lapangan kerja dan tingginya pengangguran terdidik. Sehingga, berdasarkan fakta tersebut perguruan tinggi dituntut untuk dapat membekali mahasiswanya dengan ilmu untuk menciptakan lapangan kerja, yaitu ilmu kewirausahaan. Bekal ilmu kewirausahaan tersebut akan dapat membuka mindset setiap mahasiswa agar setelah lulus nanti tidak hanya berorientasi pada mencari kerja saja, tetapi banyak peluang-peluang lain yaitu menciptakan lapangan kerja. Menjadi entrepreneur pada akhirnya nanti juga akan menjadi pilihan yang strategis untuk mencapai kesuksesan. Maka, berdasarkan hal-hal tersebut pengembangan kurikulum kewirausahaan menjadi sebuah kebutuhan untuk dapat diintegrasikan dalam kurikulum perguruan tinggi. Tujuannya untuk memberikan bekal pengetahuan, wawasan, keterampilan, mindset kewirausahaan serta strategi yang cerdas untuk menjadi entrepreneur yang sukses.

4. Mengikuti tren perguruan tinggi saat ini berbasis kewirausahaan

Mengikuti tren ini sebetulnya tidak selalu dikonotasikan negatif. Karena setiap perguruan tinggi agar tetap survive dan populer di masyarakat perlu melakukan terobosan-terobosan baru, menampilkan keunikan-keunikan baru yang dapat menjadi magnet dan daya tarik perguruan tersebut di hati masyarakat. Sehingga menjadi nilai plus dan karakteristik tersendiri yang membuat berbeda antara satu perguruan tinggi dengan perguruan tinggi yang lain. Terkait dengan tren perguruan tinggi, bahwa perguruan- 
perguruan tinggi di Singapura, Malaysia, Australia, Amerika dan Inggris memiliki kecenderungan yang cukup signifikan untuk menuju era baru, yaitu menjadikan entrepreneurship sebagai mata kuliah wajib (Hendro, 2012: 12).

Kebijakan mewajibkan entrepreneurship sebagai mata kuliah wajib tersebut ternyata berpengaruh terhadap semangat pertumbuhan sektor UKM di negara-negara tersebut. Fakta tersebut tentu saja dapat membantu program pemerintah dalam menciptakan lapangan kerja di sektor swasta.

Pertumbuhan semangat kewirausahaan di Indonesia masih sangat kecil sehingga tidak ada salahnya ketika Prodi PGMI Institut Pesantren Mathali'ul Falah dapat mengikuti tren perguruan tinggi berbasis kewirausahaan tersebut. Setidaknya, selain menampilkan keunikan dan karakter tersendiri, juga dapat memotivasi lahirnya UKM UKM dan memajukannya sehingga dapat memicu pertumbuhan ekonomi bangsa serta dapat menekan tingginya pengangguran terdidik di Indonesia. Karena perguruan tinggi tersebut dapat mencetak para lulusannya, tidak hanya sebagai pencari kerja tetapi dapat mencetak entreprener-entrepreneur muda dengan kompetensi pengetahuan, skill, konsep dan strategi yang cerdas untuk menjadikan lulusannya sukses di hari depan.

Pendidikan kewirausahaan merupakan pendidikan aplikatif yang mengarahkan peserta didik untuk dapat memahami kondisi dan selanjutnya menyadari bahwa hal terpenting dalam kehidupan adalah bagaimana kita mampu melakukan sesuatu untuk hidup dan kehidupan. Dengan pendidikan aplikatif ini, maka anak dikondisikan untuk menjalani kegiatan usaha justru pada saat mereka masih dalam proses pendidikan dan pembelajaran, sesuai dengan bidang yang dipelajarinya, atau sesuai dengan bidang kegiatan yang dibutuhkan masyarakat.

Aspek psikomotor yang selama ini diposisikan sebagai pelengkap, sudah seharusnya diberikan porsi yang lebih banyak sehingga kuantitas dan kualitas psikomotor atau keterampilan anak didik meningkat secara signifikan. Dengan kondisi ini, maka anak didik dapat menerapkan keterampilan tersebut untuk mennghadapi hidup dan kehidupan.

Apabila kondisi ini dapat diciptakan, maka secara berkelanjutan anak didik akan merasakan betapa keterampilan dapat dijadikan sebagai modal kegiatan berwirausaha dan hal tersebut sangat penting bagi kehidupannya. Sehingga Pendidikan kewirausahaan diarahkan untuk menciptakan entrepreneur yang 
inovatif dan kreatif. Karena itu, pendidikan harus memberikan arah yang jelas tujuan pendidikan kewirausahaan pada setiap level pendidikan agar semua pihak memahami hakikat yang benar dari pendidikan kewirausahaan

Perlunya Prodi PGMI Institut Pesantren Mathali'ul Falah melakukan pengembangan kurikulum berbasis kewirausahaan dengan memberikan pendidikan kewirausahaan (enterpreneurship) terintegrasi dalam kurikulum berdasarkan pertimbangan sebagai berikut:

Pertama, Prodi PGMI harus selalu responsif terhadap kebutuhan dan perkembangan masyarakat. Telaah kritis dan evaluasi terhadap kurikulum adalah sebuah keniscayaan untuk mengembangkan kurikulum yang tidak sekedar diformulasikan pada penguasaan ilmu Agama Islam saja tetapi juga bersedia untuk berbenah dalam rangka pengembangan kurikulum yang ideal sesuai dengan kebutuhan masyarakat secara umum.

Kedua, pertumbuhan semangat kewirausahaan di negara-negara maju sangat tinggi, sementara di Indonesia masih cukup kecil. Oleh karena itu, pendidikan tinggi, khususnya Prodi PGMI Institut Pesantren Mathali'ul Falah harus merubah visinya dari yang masih konvensional menjadi lebih antisipatif. Artinya PTKI tidak hanya sekedar mengantar para lulusannya memperoleh nilai tinggi tetapi juga harus mempunyai kualifikasi dan kompetensi yang dibutuhkan masyarakat dan dunia kerja. Mengintegrasikan pendidikan kewirausahaan (entrepreneurship) dalam kurikulum pendidikan dapat menjadi strategi untuk mereposisi perguruan tinggi tersebut dalam masyarakat menjadi perguruan tinggi yang qualified dan pantas untuk diperhitungkan. Bahkan, Hendro menyatakan bahwa di negara-negara lain, seperti Singapura, Malaysia, Amerika dan Inggris telah menjadikan pendidikan kewirausahaan (entrepreneurship) menjadi mata kuliah wajib (Hendro, 2011: 12).

Ketiga, untuk menumbuhkembangkan jiwa kewirausahaan (entrepreneurship) dan meningkatkan aktivitas kewirausahaan agar para lulusan perguruan tinggi lebih menjadi pencipta lapangan kerja. Zubaedi (2012: 257) menyatakan bahwa keberhasilan pendidikan kewirausahaan (entrepreneurship) dapat menjadikan para sarjana yang merupakan kelompok penduduk usia 
produktif mampu bersikap mandiri dengan menciptakan pekerjaan sendiri serta tidak menggantungkan diri pada orang lain maupun perusahaan-perusahaan besar.

Keempat, untuk memberikan keterampilan kerja (work skill) bagi mahasiswa. Keterampilan kerja tersebut menjadi nilai plus bagi lulusan Prodi PGMI karena dengan pendidikan kewirausahaan (entrepreneurship) kompetensi lulusannya tidak hanya mampu terserap dalam suatu perusahaan atau menjadi PNS di intansi tertentu, tetapi diharapkan bisa memperoleh penghidupan yang baik sesuai dengan hasil pendidikan yang telah dicapai secara mandiri (Mulyani, 2010: 16). Karena untuk mencapai kesuksesan, pengetahuan akademis saja tidak cukup untuk menjadi bekal masa depan, tetapi juga harus ditunjang dengan keterampilan kerja (work skill). Sehingga keterampilan enterpreneurial menjadi sebuah kemampuan untuk mengelola, memberdayakan dan menginternalisasi pengetahuan akademis dalam mengatasi masalah, kesulitan dan tantangan yang dihadapi yang akhirnya memunculkan kreativitas dan inovasi. Sebagaimana disyilalir Ciputra bahwa kewirausahaan atau enterpreneurship bukan hanya diartikan sebagai keterampilan bisnis, lebih penting dari itu kewirausahaan adalah sikap kreatif, inovatif dan berani mengambil keputusan sehingga dijadikan sikap hidup bahkan karakter Bangsa Indonesia (Kompas, 2009).

Kelima, Pendidikan kewirausahaan (entrepreneurship) dapat menekan tingkat pengangguran terdidik. Berdasarkan data BPS (2010) bahwa tahun 2008 pengangguran dengan pendidikan terakhir perguruan tinggi mencapai 6.936 .417 jiwa atau sekitar 7\% dari total pengangguran. Sehingga, melalui Pendidikan kewirausahaan dapat menciptakan mindset pada setiap lulusan untuk tidak hanya berorientasi pada mencari kerja saja tetapi menciptakan lapangan kerja justru lebih menarik, karena dengan menciptakan lapangan kerja terbukti menghasilkan pendapatan yang lebih besar dibandingkan dengan berkarir mencari kerja atau menjadi karyawan.

Keenam, Pendidikan kewirausahaan (entrepreneurship) dapat membantu sebuah negara untuk memiliki ketahanan di bidang ekonomi. Di Indonesia, dampak krisis ekonomi pada tahun 1997 masih terasa dan lama untuk bisa bangkit lagi. Salah satu faktor penyebabnya adalah belum banyaknya wirausahawan pada 
penduduk Indonesia. Negara maju pada umumnya memiliki wirausahawan yang lebih banyak dari negara berkembang dan negara miskin. Amerika Serikat memiliki $11,5 \%$ dari total penduduknya, Singapura $7,2 \%$, Malaysia $>3 \%$ dan Indonesia hanya $0,18 \%$. Padahal secara historis dan konsesus, apabila sebuah negara ingin maju minimal harus memiliki wirausahawan $2 \%$ dari total penduduknya (Kompas, 2008).

\section{Pengembangan Entrepreneurship di Prodi PGMI}

Pengembangan entrepreneurship di Prodi PGMI Institut Pesantren Mathali'ul Falah Pati telah dimulai dari rumusan kurikulumnya. Desain integrasi kewirausahaan dalam kurikulum tersebut disepakati dalam work shop kurikulum PGMI pada tanggal 27 Februari 2016 dengan mengacu pada hasil riset Inayatul Ulya (2014) tentang pendidikan entrepreneurship di PTKI dan analisis kebutuhan dengan beberapa stakeholder. Desain kurikulum kewirausahaan tersebut mulai terlihat dalam misi Prodi PGMI. Diantara misi Prodi PGMI Institut Pesantren Mathali'ul Falah tersebut memuat "mengembangkan PGMI berwawasan IPTEK dan entrepreneurship". Misi lengkap Prodi PGMI Institut Pesantren Mathali'ul Falah adalah sebagai berikut (Dokumen Kurikulum Prodi PGMI Institut Pesantren Mathali'ul Falah):

1. Menyelenggarakan PGMI yang profesional dan berorientasi pada kompetensi lulusan

2. Melaksanakan riset dan kajian di bidang Pendidikan Dasar Islam

3. MengembangkanPGMI yang berbasis nilai-nilai pesantren dan akhlakul karimah

4. Mengembangkan PGMI berwawasan iptek dan entrepreneurship

5. Meningkatkan peran serta jurusan PGMI melalui pengabdian masyarakat

6. Menjalin kerjasama dengan berbagai pihak.

Entrepreneurship dalam misi Prodi PGMI Institut Pesantren Mathali'ul Falah tersebut ingin menunjukkan distingsi yang dipilih oleh Prodi PGMI, yang menjadi pembeda dengan Prodi PGMI pada perguruan tinggi lainnya. Entrepreneurship dalam hal ini diposisikan sebagai kompetensi lain yang dimiliki 
oleh Prodi PGMI Institut Pesantren Mathali'ul Falah setelah kompetensi utama dan kompetensi pendukung.

Berdasarkan misi tersebut kemudian dijabarkan dalam tujuan penyelenggaraan Prodi PGMI sebagai berikut:

1. Menghasilkan pendidik MI yang profesional dan kompeten.

2. Menghasilkan peneliti pendidikan dasar Islam yang produktif

3. Menghasilkan pembina insan shaleh akram yang handal

4. Menghasilkan perancang sarana pembelajaran untuk pendidikan dasar Islam dan bermental entrepreneurship

5. Menghasilkan konsultan lembaga pendidikan dasar Islam yang handal dan kompeten.

6. Mewujudkan kerjasama dengan berbagai pihak

Diantara tujuan penyelenggaraan Prodi PGMI Institut Pesantren Mathali'ul Falah adalah menghasilkan perancang sarana pembelajaran untuk pendidikan dasar Islam dan bermental entrepreneurship. Prodi PGMI Institut Pesantren Mathali'ul Falah dalam hal ini menekankan entrepreneurship dapat menjadi jiwa dan karakter yang melekat pada mahasiswanya. Nilai-nilai kewirausahaan ini meliputi nilai karakter wirausaha yang diharapkan dapat terinternalisasi dalam pola fikir, pola sikap dan pola tindakan yang dimiliki lulusan PTKI. Nilai-nilai tersebut antara lain: Mandiri, kreatif, inovatif, percaya diri, berorientasi pada tugas dan tindakan, berani mengambil resiko, kepemimpinan, berorientasi ke depan, kerja keras, jujur, disiplin, rasa ingin tahu dan motivasi untuk maju.

Lulusan Prodi PGMI Institut Pesantren Mathali'ul Falah hendaklah memiliki karakteristik dan jiwa kewirausahaan tersebut sebagai fondasi dasar dalam melangkah menjadi seorang entrepreneur karena pada prinsipnya transformasi nilai sekaligus mindset kewirausahaan ini adalah proses dasar dalam memulai berwirausaha. Karena untuk menjadi entrepreneur yang sukses diperlukan beberapa langkah transformasi pola pikir dan paradigma agar dapat menjalankan bisnis.

Adapun tahapan tahapan proses transformasi karakter dan mindset kewirausahaan lulusan Prodi PGMI adalah sebagai berikut: 
1. Transformasi pola pikir (mindset) dan paradigma (paradigm), yaitu sebuah transformasi pemikiran, sikap, motif, semangat dan karakter untuk berubah menjadi seseorang yang berfikiran sama dengan seorang entrepreneur yang cerdas.

2. Transformasi cara berpikir lama untuk berubah. Berubah dari kebiasaan yang selalu menggunakan logika ke pola pikir kreatif dalam menemukan inspirasi, ide dan peluang bisnis. Cara berpikir yang perlu ditransformasi adalah menghindari jebakan logika, berpikir berbeda dengan orang lain, menjadikan pengetahuan dan pendidikan sebagai media dalam menemukan inspirasi melalui pola pikir yang kreatif dan inovatif serta berpikir visioner.

3. Transformasi entrepreneurial dari bersikap sebagai entrepreneur (owner) menjadi manajer pengelola bisnis (intrapreneur atau entrepreneurial organization) yang profesional. Menjadi entrepreneur yang berpikir sebagai pemilik, pendiri dan penggagas sebuah bisnis itu berbeda dengan intrapreneur yang bertindak sebagai pengelola, manajer, pemimpin dan pelaksana strategi yang bertujuan untuk mewujudkan visi dan misi pendiri bisnis.

4. Transformasi entrepreneurial dari pola pikir owner ke pola pikir sebagai investor. Setelah pebisnis itu sukses, pola pikirnya berkembang ingin menjadi seorang investor untuk mengembangkan bisnisnya melalui ekspansi bisnis, membali bisnis, meng-franchise-kan bisnis dan meningkatkan nilai-nilai perusahaan hingga mengarah pada peningkatan nilai aset riil yang tinggi secara tangible dan intangible sehingga sebuah perusahaan tidak dinilai dari aset riil tetapi telah berubah menjadi sebuah aset yang tidak ternilai harganya (Hendro, 2011: 61).

Selain misi dan tujuan, profil lulusan Prodi PGMI Institut Pesantren Mathali'ul Falah juga mencantumkan "menjadi entrepreneur bidang pendidikan dasar dan bidang lainnya. Profil lulusan Prodi PGMI Institut Pesantren Mathali'ul Falah secara lengkap sebagai berikut:

1. Guru Kelas MI yang kompeten dan shalih akram

2. Peneliti bidang pendidikan dasar Islam 
3. Konsultan lembaga pendidikan dasar Islam

4. Entrepreneur bidang pendidikan dasar dan bidang lainnya

Entrepreneur bidang pendidikan dasar dan bidang lainnya tersebut menjadi salah satu profil lulusan untuk mengantisipasi lulusan yang tidak semuanya dapat terserap ke dunia kerja. Ada kemungkinan, tidak semua lulusan Prodi PGMI dapat semuanya menjadi guru MI. Prodi PGMI Institut Pesantren Mathali'ul Falah menyiapkan sejumlah skill menjadi entrepreneur agar lulusan dapat tetap survive dalam hidupnya dan dapat menghadapi hari depannya. Kualifikasi kewirausahaan (entrepreneurship) ini masuk dalam kategori kompetensi lain yang harus dimiliki lulusan Prodi PGMI. Kompetensi kewirausahaan ini sebenarnya sebagai pelengkap kompetensi yang harus dimiliki lulusan Prodi PGMI. Sebagai lulusan PTKI (Perguruan Tinggi Keagamaan Islam) tentu saja memiliki kompetensi utama dalam hal penguasaan ilmu-ilmu keIslaman yang mampu melaksanakan tugas dan fungsi sebagai ahli Agama Islam. Sedangkan kompetensi kewirausahaan ini adalah kompetensi minor yang menjadi nilai plus lulusan karena mempunyai kompetensi lain di bidang kewirausahaan. Jadi, jika kualifikasi tersebut dimiliki oleh lulusan Prodi PGMI, maka tidak akan ada lulusan Prodi PGMI yang menganggur karena mereka dapat berkiprah dan mendedikasikan diri tidak terbatas satu bidang yang linear dengan keilmuannya saja. Mereka bisa survive menjadi guru MI maupun menjadi wirausaha.

Kompetensi kewirausahaan dapat diberikan melalui serangkaian program dan pengalaman belajar di Prodi PGMI baik dari keilmuan secara teoritisnya dan maupun pengalaman berwirausaha yang difasilitasi Prodi PGMI serta kemampuan untuk bekerjasama dengan sektor-sektor yang strategis seperti dunia industri melalui proses pemagangan dan lain-lain. Hal ini dilakukan dalam rangka transfer of knowledge, skill dan experience terhadap mahasiswa Prodi PGMI melalui pembelajaran teoritis dan praktek kewirausahaan untuk menginternalisasikan jiwa dan mindset kewirausahaan secara berkesinambungan dan mempunyai sistem pengelolaan yang terencana, sistematis dan berkelanjutan. 
Berikut beberapa program pengembangan entrepreneurship di Prodi PGMI dilengkapi dengan pemetaan identifikasi masalah, identifikasi potensi lembaga, bentuk kegiatan dan hasil yang diharapkan. 
Tabel 1. Program Pengembangan Entrepreneurship di Prodi PGMI IPMAFA Pati

\begin{tabular}{|c|c|c|c|c|c|}
\hline NO & IDENTIFIKASI MASALAH & $\begin{array}{c}\text { IDENTIFIKASI POTENSI } \\
\text { LEMBAGA }\end{array}$ & $\begin{array}{c}\text { NET } \\
\text { WORKING } \\
\end{array}$ & BENTUK KEGIATAN & $\begin{array}{l}\text { HASIL YANG } \\
\text { DIINGINKAN }\end{array}$ \\
\hline 1. & $\begin{array}{l}\text {-Prodi PGMI secara umum tidak } \\
\text { memberikan bekal-bekal teori } \\
\text { kewirausahaan karena dianggap } \\
\text { tidak linear dengan keilmuan } \\
\text { pendidikan } \\
\text {-Prodi PGMI di IPMAFA } \\
\text { merupakan Prodi baru yang baru } \\
\text { memiliki izin operasional pada } \\
\text { Juni } 2015 \text { dan belum memiliki } \\
\text { distingsi sebagai nilai plus dan } \\
\text { ciri khas serta karakteristik dalam } \\
\text { pendidikannya } \\
\text {-Prodi PGMI secara umum kurang } \\
\text { responsif terhadap perkembangan } \\
\text { zaman } \\
\text {-Tidak semua lulusan Prodi PGMI } \\
\text { akan seluruhnya terserap ke dunia } \\
\text { kerja sebagai guru di tingkat MI, } \\
\text { maka perlu alternatif lain agar } \\
\text { lulusan Prodi PGMI tidak menjadi } \\
\text { pengangguran terdidik }\end{array}$ & $\begin{array}{l}\text {-Hasil workshop Prodi PGMI } \\
\text { Institut Pesantren Mathali'ul Falah } \\
\text { merekomendasikan untuk memberi } \\
\text { distingsi sebagai nilai plus dan } \\
\text { karakteristik khusus yang } \\
\text { membedakan dengan prodi PGMI } \\
\text { lainnya. Dan entrepreneurship } \\
\text { dipilih untuk menjadi distingsi dan } \\
\text { kekhasan pada Prodi PGMI Institut } \\
\text { Pesantren Mathali'ul Falah } \\
\text {-Prodi PGMI perlu memberikan } \\
\text { skill kewirausahaan sebagai bekal } \\
\text { lulusan Prodi PGMI untuk tetap } \\
\text { survive dalam kehidupan apabila } \\
\text { lulusan tidak semuanya terserap } \\
\text { dalam dunia kerja } \\
\text {-upaya responsif terhadap tuntutan } \\
\text { zaman sekaligus menjadi solusi atas } \\
\text { rendahnya link and match ( } \\
\text { kesesuaian kebutuhan kerja dan } \\
\text { kompetensi lulusan) dalam dunia } \\
\text { pendidikan }\end{array}$ & $\begin{array}{l}\text {-AD-PGMI } \\
\text { Indonesia }\end{array}$ & $\begin{array}{l}\text { Memasukkan } \\
\text { kewirausahaan sebagai } \\
\text { mata kuliah wajib di Prodi } \\
\text { PGMI dengan nama Mata } \\
\text { Kuliah: } \\
\text { Edupreneurship I dan } \\
\text { Edupreneurship II }\end{array}$ & $\begin{array}{l}\text { Mahasiswa dapat } \\
\text { memahami teori-teori } \\
\text { kewirausahaan dan } \\
\text { mampu } \\
\text { mempraktekkannya }\end{array}$ \\
\hline 2. & $\begin{array}{l}\text {-Mahasiswa dan dosen } \\
\text { secara umum tidak memiliki } \\
\text { mindset dan skill kewirausahaan } \\
\text {-Mata kuliah Edupreneurship I } \\
\text { dan II kurang maksimal hasilnya } \\
\text { sehingga perlu program tambahan } \\
\text { yang relevan }\end{array}$ & $\begin{array}{l}\text { Banyak mahasiswa yang memiliki } \\
\text { minat berwirausaha }\end{array}$ & $\begin{array}{l}\text { CEC (Ciputra } \\
\text { Entrepreneurshi } \\
p \text { Center) } \\
\text { Jakarta }\end{array}$ & $\begin{array}{l}\text { Pelatihan Kewirausahaan } \\
\text { untuk mahasiswa dan dosen }\end{array}$ & $\begin{array}{l}\text { Mahasiswa dan dosen } \\
\text { memiliki jiwa } \\
\text { kewirausahaan dan } \\
\text { mampu } \\
\text { menginternalisasikan } \\
\text { dalam kehidupan }\end{array}$ \\
\hline 3. & $\begin{array}{l}\text {-Secara umum mahasiswa tidak } \\
\text { memiliki pemahaman tentang } \\
\text { dunia industri tentang bagaimana } \\
\text { usaha dijalankan dan dipasarkan }\end{array}$ & $\begin{array}{l}\text {-Di Pati banyak beberapa } \\
\text { perusahaan industri besar maupun } \\
\text { home industry yang bisa dijadikan } \\
\text { laboratorium untuk belajar }\end{array}$ & $\begin{array}{l}\text {-PT. Garuda } \\
\text { Food } \\
\text {-PT. Dwi } \\
\text { Kelinci }\end{array}$ & $\begin{array}{l}\text { Pemagangan mahasiswa } \\
\text { pada dunia industri }\end{array}$ & $\begin{array}{l}\text { Mahasiswa dapat belajar } \\
\text { langsung dari dunia } \\
\text { industri tentang } \\
\text { bagaimana }\end{array}$ \\
\hline
\end{tabular}


IMPLEMENTASI PENGEMBANGAN ENTERPRENEURSHIP

\begin{tabular}{|c|c|c|c|c|c|}
\hline & & berwirausaha & $\begin{array}{l}\text {-Home Industry } \\
\text { di sekitar Pati }\end{array}$ & & $\begin{array}{l}\text { merencanakan usaha, } \\
\text { memproduksi dan } \\
\text { memasarkannya }\end{array}$ \\
\hline 4. & $\begin{array}{l}\text {-Mahasiswa banyak yang belum } \\
\text { memahami bagaimana } \\
\text { merencanakan dan merasakan } \\
\text { langsung pengalaman } \\
\text { berwirausaha }\end{array}$ & $\begin{array}{l}\text {-Prodi PGMI telah menfasilitasi } \\
\text { mahasiswa dengan mata kuliah } \\
\text { Edupreneurship I yang mempelajari } \\
\text { teori-teori kewirausahaan dan } \\
\text { program pemagangan pada dunia } \\
\text { industri serta Mata Kuliah } \\
\text { Edupreneurship II yang fokus pada } \\
\text { materi pembuatan bisnis plan dan } \\
\text { praktek berwirausaha }\end{array}$ & $\begin{array}{l}\text {-Koperasi Mafa } \\
\text { Sejahtera }\end{array}$ & $\begin{array}{l}\text { Membentuk inkubator } \\
\text { bisnis }\end{array}$ & $\begin{array}{l}\text { Mahasiswa dapat } \\
\text { merasakan pengalaman } \\
\text { berwirausaha dengan } \\
\text { praktek berwirausahaha }\end{array}$ \\
\hline 5. & $\begin{array}{l}\text { Banyak lulusan perguruan tinggi } \\
\text { yang bingung apa yang harus } \\
\text { dilakukan setelah lulus. } \\
\text { Bagaimana cara melamar kerja, } \\
\text { lembaga mana saja yang bisa } \\
\text { dituju serta syarat-syarat apa saja } \\
\text { yang dibutuhkan }\end{array}$ & $\begin{array}{l}\text { Banyak lembaga disekitar Pati yang } \\
\text { relevan untuk diajak kerjasama } \\
\text { untuk memberikan pemahaman } \\
\text { tentang pentingnya mempersiapkan } \\
\text { karir pasca wisuda, tentang } \\
\text { bagaimana cara membuat surat } \\
\text { lamaran pekerjaan, instansi apa } \\
\text { yang bisa dituju dan beberapa } \\
\text { syarat yang dibutuhkan pada setiap } \\
\text { instansi. }\end{array}$ & $\begin{array}{l}\text {-Dinas } \\
\text { Pendidikan dan } \\
\text { Kebudayaan } \\
\text { Pati, } \\
\text {-KEMENAG } \\
\text { Pati, } \\
\text {-Lembaga } \\
\text { Madrasah } \\
\text { Ibtidaiyah di } \\
\text { Pati }\end{array}$ & $\begin{array}{l}\text { Pelatihan Pengembangan } \\
\text { Karir }\end{array}$ & $\begin{array}{l}\text { Mahasiswa dapat } \\
\text { menyiapkan diri untuk } \\
\text { memasuki dunia kerja, } \\
\text { mengetahui instansi } \\
\text { yang akan dituju dan } \\
\text { memahami syarat-syarat } \\
\text { yang diperlukan }\end{array}$ \\
\hline 6. & $\begin{array}{l}\text { Belum adanya lembaga di Prodi } \\
\text { PGMI yang fokus menangani } \\
\text { kewirausahaan dan } \\
\text { pengembangan karir mahasiswa }\end{array}$ & $\begin{array}{l}\text { Prodi PGMI memiliki SDM dosen } \\
\text { yang bisa diberdayakan untuk } \\
\text { mengelola unit kewirausahaan dan } \\
\text { pusat pengembangan karir tersebut }\end{array}$ & $\begin{array}{l}\text { Center for } \\
\text { Entrepreneurshi } \\
p \text { and Career } \\
\text { Studies } \\
\text { (CENDI) UIN } \\
\text { Sunan Kalijaga } \\
\text { Yogyakarta }\end{array}$ & $\begin{array}{l}\text { Mendirikan unit } \\
\text { kewirausahaan dan } \\
\text { pengembangan karir di } \\
\text { prodi PGMI dengan nama } \\
\text { Edupreneurship and } \\
\text { Career development Centre } \\
\text { (ECDC) }\end{array}$ & $\begin{array}{l}\text { Prodi PGMI memiliki } \\
\text { Unit Kewirausahaan dan } \\
\text { Pusat pengembangan } \\
\text { karir }\end{array}$ \\
\hline
\end{tabular}


Berdasarkan hasil pemetaan identifikasi masalah dan potensi tersebut, Prodi PGMI Institut Pesantren Mathali'ul Falah akan memposisikan kewirausahaan sebagai skill yang harus dimiliki mahasiswa Prodi PGMI sebagai bentuk capaian kompetensi lain di Prodi PGMI, selain keharusan menguasai kompetensi utama dalam hal Islamic Studies dan kompetensi pendukung dalam hal ilmu-ilmu pendidikan dan keguruan.

\section{Kesimpulan}

Banyak problematika yang muncul dalam pendidikan tinggi, diantaranya banyak lulusan pendidikan tinggi yang tidak mampu terserap dalam dunia kerja. pengangguran khususnya lulusan pendidikan tinggi menjadi masalah yang cukup beralasan untuk segera dicarikan alternatif solusi. Problematika lain yang dihadapi pendidikan tinggi adalah rendahnya kompetensi lulusannya sehingga out put dari pendidikan tinggi belum mempunyai kompetensi yang diharapkan dan dibutuhkan masyarakat serta mempunyai daya saing rendah dalam dunia kerja. Sehingga, sebagian besar lulusan perguruan tinggi cenderung lebih sebagai pencari kerja (job seeker) daripada pencipta lapangan pekerjaan (job creator). Begitu pula dalam hal lulusan Prodi PGMI, ada kemungkinan tidak semuanya dapat terserap menjadi guru MI karena terbatasnya lembaga pendidikan MI dan peluang kerjanya yang tidak seimbang dengan jumlah lulusan yang semakin banyak setiap tahunnya. Pengembangan Entrepreneurship di Prodi PGMI Institut Pesantren Mathali'ul Falah dilakukan secara bertahap, mulai dari mengintegrasikan kewirausahaan dalam kurikulum yang tertuang dalam misi, tujuan, profil lulusan serta realisasi melalui mata kuliah serta program-program lain untuk peningkatan skill kewirausahaan. Program-program tersebut berupa pelatihan kewirausahaan, pemagangan mahasiswa dalam dunia industri, pembentukan inkubator bisnis, pengembangan karir dan pendirian unit kewirausahaan. 


\section{Daftar Pustaka}

Adams, L. M. (1965). Webster's New American Dictionary. New York: Books INC.

Badan Pusat Statistik, 2009.

Badan Pusat Statistik, 2010.

Burhan, N. (tt.). Dasar-Dasar Pengembangan Kurikulum Sekolah: Sebuah Pengantar Teoritis dan Pelaksanaan. Yogyakarta: IKIP.

Ciputra, Kompas, 30 Nopember 2009.

Dakir, H. (2010). Perencanaan dan Pengembangan Kurikulum. Jakarta: PT. Rineka Cipta.

Hendro. (2011). Dasar-Dasar Kewirausahaan: Panduan bagi Mahasiswa untuk Mengenal, Memahami dan Memasuki Dunia Bisnis. Jakarta: Erlangga.

Hendyat, S. dan Wasty, S. (1993). Pembinaan dan Pengembangan Kurikulum sebagai Substansi Problem Administrasi Pendidikan, Jakarta: Bumi Aksara.

Hutchin, R. M. (1998). Pendidikan Liberal Sejati dalam Menggugat Pendidikan: Fundamentalis, Konservatif, Liberal, Anarkhis. Yogyakarta: Pustaka Pelajar.

Jurnal Economia. (2012). Volume 8, Nomor 1.

Jurnal Ilmiah Inkoma. (2011). Volume 22, Nomor 1.

Mulyani, E., dkk. (2010). Pengembangan Pendidikan Kewirausahaan: Bahan Pelatihan Penguatan Metodologi Pembelajaran Berdasarkan Nilai-nilai Budaya Untuk Meembentuk Daya Saing dan Karakter Bangsa. Jakarta: Pusat Kurikulum Badan Pengembangan dan Pelatihan Kemendiknas.

Nasution. (1995). Asas-Asas Kurikulum. Jakarta: Bumi Aksara.

Ning Tias, D. R. (2009). "Hubungan antara Motivasi Berprestasi dengan Enterpreneurship pada Mahasiswa UMS," Skripsi, Fakultas Psikologi UMS Solo: Tidak Diterbitkan.

Oemar, H. (1993). Pengembangan Kurikulum. Jakarta: Bumi Aksara.

Propenas. (2004). 
Ruwiyanto, W. (1994). Peranan Pendidikan dalam Pengentasan Masyarakat Miskin Pendekatan Analisis Organisasi Secara Kuantitatif. Jakarta: Rajawali.

Sukmadinata, N. S. (2010). Pengembangan Kurikulum: Teori dan Praktek, Bandung: PT. Remaja Rosdakarya.

Ulya, I. (2014). Pendidikan Entrepreneurship di PTKI (Paradigma Pengembangan Kurikulum Berbasis Kewirausahaan). Penelitian Tahun 2014.

Winarno, FG. (tt.). Pengangguran Intelektual Bertambah 20\% Per-Tahun dalam http://www.atmajaya.ac.id diakses 30 April 2013.

Zimmerer, W., Scarborough, N. M., dan Wilson, D. (2008). Essentials of Enterpreneurship and Small Business Management, (terjemahan Deny Arnos Kwary dan Dewi Fitria Sari, Kewirausahaan dan Manajemen Usaha Kecil, Jakarta: Salemba Empat.

Zubaedi, (2012). Filsafat Pendidikan Islam. Yogyakarta: Pustaka Pelajar. 